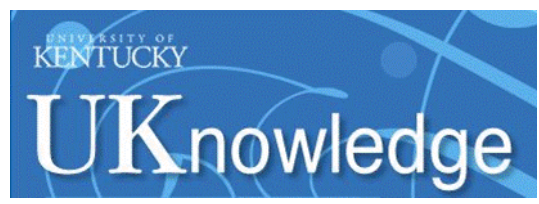

University of Kentucky

UKnowledge

$11-16-2020$

\title{
Supporting School Readiness through Librarian-Child Interactions in Public Library Storytimes: An Analysis of Assessment Scores and Influential Factors
}

\author{
Maria Cahill \\ University of Kentucky, maria.cahill@uky.edu \\ Hayley Hoffman \\ University of Kentucky, hayley.hoffman@uky.edu \\ Erin E. Ingram \\ University of Kentucky, Erin.Ingram@uky.edu \\ Soohyung Joo \\ University of Kentucky, soohyung.joo@uky.edu
}

Follow this and additional works at: https://uknowledge.uky.edu/slis_facpub

Part of the Early Childhood Education Commons, and the Library and Information Science Commons Right click to open a feedback form in a new tab to let us know how this document benefits you.

\section{Repository Citation}

Cahill, Maria; Hoffman, Hayley; Ingram, Erin E.; and Joo, Soohyung, "Supporting School Readiness through Librarian-Child Interactions in Public Library Storytimes: An Analysis of Assessment Scores and Influential Factors" (2020). Information Science Faculty Publications. 79.

https://uknowledge.uky.edu/slis_facpub/79

This Article is brought to you for free and open access by the Information Science at UKnowledge. It has been accepted for inclusion in Information Science Faculty Publications by an authorized administrator of UKnowledge. For more information, please contact UKnowledge@lsv.uky.edu. 


\section{Supporting School Readiness through Librarian-Child Interactions in Public Library Storytimes: An Analysis of Assessment Scores and Influential Factors}

Digital Object Identifier (DOI)

https://doi.org/10.1007/s10643-020-01133-6

Notes/Citation Information

Published in Early Childhood Education Journal.

(C) 2021 Springer Nature Switzerland AG.

This is a post-peer-review, pre-copyedit version of an article published in Early Childhood Education Journal. The final authenticated version is available online at: https://doi.org/10.1007/ s10643-020-01133-6 
Cahill, M., Hoffman, H., Ingram, E. et al. Supporting School Readiness Through Librarian-Child Interactions in Public Library Storytimes: An Analysis of Assessment Scores and Influential Factors. Early Childhood Educ J (2020). https://doi.org/10.1007/s10643-020-01133-6

\section{Title}

Supporting school readiness through librarian-child interactions in storytimes: An analysis of assessment scores and influential factors

Maria Cahill, University of Kentucky, maria.cahill@uky.edu, ORCID: 0000-0003-4140-3570 Hayley Hoffman, University of Kentucky, hayley.hoffman@uky.edu, 0000-0002-5098-7646 Erin Ingram, University of Kentucky, erin.ingram@uky.edu

Soohyung Joo, University of Kentucky, soohyung.joo@uky.edu, ORCID: 0000-0001-6770-5118

\section{Acknowledgments}

We express sincere gratitude to Mary Howard, University of Kentucky Human Development Institute, for her contributions to this study and to Janet Ingraham Dwyer, State Library of Ohio; Krista King-Oaks, Boone County (KY) Public Library, and Suzanne Walker and Beth Yates, Indiana State Library for support of this project.

\section{Declarations}

Funding

This work was supported by the Institute of Museum and Library Services [Federal Award Identification Number: LG-96-17-0199-17].

Conflicts of interest/Competing interests Not applicable

\section{Ethics approval}

All procedures performed in studies involving human participants were in accordance with the ethical standards of the institutional and/or national research committee and with the 1964 Helsinki Declaration and its later amendments or comparable ethical standards. The investigation was approved by the University of Kentucky's institutional review board (IRB number 42829 .

\section{Consent to Participate}

Approval to conduct the study was obtained from each of the participating library systems. While no identifying information about any participants was included in this paper, informed consent was obtained from the participating librarians. 
Consent for publication not applicable

Availability of data and material Not applicable

Code availability (software application or custom code) Not applicable

Author contributions

Maria Cahill and Soohyung Joo contributed to the study conception and design. Material

preparation, data collection and analysis were performed by Maria Cahill, Hayley Hoffman, and

Soohyung Joo. The first draft of the manuscript was collaboratively written by all authors. 


\begin{abstract}
A recent trend in public libraries children's services emphasizes the role of promoting school readiness. In order to gain a deeper understanding of the school readiness efforts present in storytime programs, this study observed and scored 68 public library preschool storytime sessions presented by 35 storytime providers across three states using the CLASS (Classroom Assessment Scoring System) measure. The CLASS evaluates adult-child interactions in learning environments within three domains related to positive outcomes in children's school readiness: emotional support, classroom organization, and instructional support. Additionally, the study examined whether differences among CLASS scores were influenced by the population density of the library community, the storytime provider's degree status and educational level, the provider's prior teaching experience, the provider's years of experience in children's services, and the number of children participating in the storytime session. Results revealed that storytime providers score well in the CLASS's emotional support and classroom organization dimensions but have room for improvement in the content-focused instructional support domain. Of the factors examined, only years of experience in children's services was found to influence a provider's CLASS score. These findings suggest that professional development programs should focus on preparing librarians to teach and model school readiness skills during storytime.
\end{abstract}

\title{
Keywords
}

school readiness, adult-child interactions, public libraries, storytimes

\section{Introduction}

Experiences and interactions in early childhood have profound effects on physical and cognitive development and serve as building blocks for future success. Language and literacy skills impact overall academic success (NICHD 2005), and skills, such as paying attention, getting along with others, and persistence also serve as important indicators of school readiness (Arnold Kupersmidt, Vogler-Lee and Marshall 2012). Yet, there is great variation in school readiness, with only one-third of children in the US able to recognize letters upon school entry (Child Trends 2015). This discrepancy in abilities and readiness is particularly concerning given that differences tend to persist across the school years (Dickinson and Porche 2011).

Public libraries provide rich learning opportunities for young children and their caregivers (Hill, Proffitt, Streams and OCLC 2015), and library services are particularly important for children ages 3-5 years, fewer than half of whom in the United States are enrolled in preschool programs (Hussar, National Center for Education Statistics, Zhang, Hein, Wang, Roberts, et al. 2020). Storytimes are among the most highly regarded and frequently attended programs offered in public libraries, and they have realized significant attendance growth in the past decade (Institute of Museum and Library Services 2020). Storytimes are intended to be enjoyable, support the learning and well-being of young children, and satisfy broader community needs (Cahill, Joo, Howard, Ingraham-Dwyer, King-Oaks and Yates 2020), but measuring the outcomes of these 
programs is difficult, particularly because use of traditional assessments would be inappropriate. Nevertheless, in an era of accountability with funding tied to measures of performance (Haycock 2016), libraries are keen to demonstrate the value of the programs they provide, and librarians are eager to improve their craft. This analysis, part of a larger study focused on public library storytime programs, examines the quality of librarian-child interactions in public library storytime programs and the extent to which those interactions support children's development and school readiness.

\section{Literature review}

\section{Brief overview of storytimes}

Storytime programs are a regular component of public library services for children around the world (Goulding, Dickie and Shuker 2017; McKend 2010). Reading aloud from carefully selected books is a common denominator of these programs, with many librarians expressing the goal of instilling a love of reading (Goulding et al. 2017; McKend, 2010; Neuman, Moland and Celano 2017). Stories are also shared orally, often with the use of puppets, flannel boards, or other props (Campana 2018; McKend 2010). Other common storytime elements include: rhymes, songs, and music, which tend to involve corresponding gross motor movements; fingerplays; crafts; and guided play (Campana 2018; Neuman et al. 2017). In most modern storytimes, children and accompanying adults interact with the librarian and one another, eschewing the traditional image of children sitting silently in rows simply listening to a story (Neuman et al. 2017).

A focus on storytime programs as a way to help children develop early literacy skills emerged in the early 2000s with the creation of the Every Child Ready to Read (ECRR) (Campana, Mills, Capps, Dresang, Carlyle, Metoyer et al. 2016). A major change that the ECRR program brought to storytimes is the view that librarians can best help children develop early literacy skills not only by directly teaching the children but also by modeling for and teaching parents and caregivers how to teach early literacy skills (Neuman et al. 2017). As of 2017, over six thousand libraries had purchased the ECRR Toolkit for training in the use of this framework in children's programming (Neuman et al. 2017), and its influence extends across the world (Goulding et al. 2017; McKend 2010).

\section{Storytimes as a context for supporting school readiness}

A recent trend in public library services for children is an emphasis on promoting school readiness. School readiness encompasses a variety of skills, behaviors, and knowledge that children are meant to develop in order to enter school ready to be successful. The Early Learning Outcomes Framework (Office of Head Start,2015) details five domains of school readiness: approaches to learning; cognition; language and literacy; perceptual, motor, and physical development; and social and emotional development. While skills and knowledge in the 
language and literacy domain may be at the forefront of a storytime provider's mind, the other domains are regularly addressed throughout programs (Campana 2018).

School readiness goals pair naturally and easily with early literacy goals in library programs for children. Children in storytimes in Canada demonstrated school readiness behaviors such as following directions and taking turns, and many parents and caregivers identified the development of these skills as a primary goal in attending the programs. These findings led the researchers to argue that "school readiness goals should be considered when developing early literacy library programs" (Peterson, Jang, Jupiter and Dunlop 2012, p. 14). Similarly, based on a survey of public libraries and museums in Philadelphia, United States, Sirinides and colleagues (2017) argue that libraries are positioned well to continue and expand these efforts to support national early education goals in informal environments.

In addition to a recognition that library programs for children in general promote school readiness, research has found that storytimes in particular can help children develop school readiness knowledge and behaviors. From observations of 120 public library storytime sessions in Washington, United States, Campana (2018) found that math, science, and literacy content knowledge were conveyed in at least $80 \%$ of the sessions while social and emotional information content was included in $40 \%$ and $50 \%$ of the sessions, respectively. Campana (2018) also administered surveys to storytime providers in Washington and found that the skills encouraged by the highest percentage of respondents correspond to all five domains of school readiness (Office of Head Start 2015).

\section{Teaching through Interactions framework and CLASS}

It is widely accepted that learning is dependent upon the quality of interactions between the learner and the instructor, with several developmental theories supporting this claim. Bowlby's (1958) attachment theory, for example, asserts that a strong connection to at least one caregiver is crucial for development; similarly, Vygotsky's sociocultural theory argues that learning comes down to a social interaction with a more knowledgeable individual who transmits some aspect of knowledge to the learner through language (John-Steiner and Mahn 1996). Framed by these theories, numerous studies have found that the quality of teacher-student interactions influence student learning (Hamre, Pianta, Downer, DeCoster, Mashburn, Jones et al. 2013).

As originally posited by Hamre and colleagues (2013), the Teaching through Interactions framework attempts to address two gaps in the current literature. First, it identifies three specific processes that lead to learning: emotional support, classroom organization, and instructional support. Emotional support concerns teacher efforts to support social and emotional development in the classroom through positive teacher-student and student-student interactions. Classroom organization concerns the way in which classrooms are ordered to promote learning. Instructional support concerns the quality of lessons and feedback provided from teacher to student. Working in tandem, the integration of these three processes into the classroom leads to learning. Second, this framework anchors these processes in indicators that can be observed in everyday teaching interactions. When looking for emotional support in the classroom, observers 
should find: the development of positive climate; the absence of negative climate; responsivity to students' needs and general teacher sensitivity; displays of regard for student perspectives; and the absence of over control or regimented scheduling instituted at the expense of learning. When looking for classroom organization, observers should find: effective behavior management of classroom chaos; general productivity during class time; and a variety of instructional learning formats used during lessons. When looking for instructional support, observers should find the promotion of students' higher-order thinking through concept development and quality of feedback provided between the teacher and her students, as well as teacher utilization of language modeling to encourage language development as well as richness of instructional methods during lessons. Drawing from these processes and domains, the Teaching through Interactions framework serves as the basis for the Classroom Assessment Scoring System (Pianta, LaParo and Hamre 2013).

The Classroom Assessment Scoring System Pre-K (CLASS; Pianta et al. 2013) was designed to evaluate classrooms and learning environments for preschool aged children across Hamre and colleagues' (2013) three domains: emotional support, classroom organization, and instructional support. CLASS allows for interactions to be "reliably observed and assessed" (Hamre et al. 2013 , p. 463) within the learning environment and creates a common standard for quality in teaching. Among classrooms making use of the CLASS are Head Start preschools, where over 200 research studies demonstrate that children with higher-scoring Head Start teachers - and thus, more effective facilitators of teacher-student interactions - had better social and academic outcomes than their peers with low-scoring teachers (Pianta et al. 2013). A study which examined the use of the CLASS to rate early childhood education programs in the state of Louisiana, found similar results: children with higher-scoring teachers made greater gains across various domains of development throughout the academic year by (Vitiello, Bassok, Hamre, Player and Williford 2018).

It is clear, then, that the CLASS does do what it set out to do - that is, provide a reliable observation instrument that documents the impact effective adult-child interactions can have on learning. Given a push in public libraries to position storytime programs to support school readiness coupled with the necessity of quality interactions as a condition for optimal learning, this study sought to use the CLASS as an indicator of the quality of librarian-child interactions in public library storytimes, and one indicator of the role of storytime in supporting school readiness. From this goal, we derived the following research question and sub-question:

To what extent are the interactions between the librarian and children in public library storytimes supportive of children's learning and development?

Do any of the following factors influence the quality of the interactions between the librarian and children in public library storytimes?

- population density of the library service area

- librarian's qualifications, including master's degree from a library and information science (LIS) program, educational level, teaching experience, or experience in children's services

- the number of child participants 


\section{Methods}

\section{Context and participants}

The current study, nested in a larger, multi-state investigation of public library storytime programs designed for children ages 3- to 5-years-old, examined the interactions between librarians and children. The investigation was approved by the University of Kentucky's institutional review board (IRB number 42829.

We invited all public libraries within 135 counties across three states (i.e., Kentucky, Ohio, and Indiana) to participate, and from those who responded, we drew a stratified random sample of 36 libraries based upon population of the legal service area and rural/urban designation. Prior to data collection, one participating library dropped out of the study after a decision to stop offering preschool storytimes (in lieu of offering storytime programs for younger children). The remaining participating libraries are relatively evenly distributed across community size categories: 12 urban areas, 12 suburban areas (i.e. urban clusters), and 11 rural areas based on the location code ascribed by the IMLS (2016) Public Library Survey.

The preparation and years of experience of the storytime providers (henceforth referred to as librarians, though not all were formally trained to be librarians) varied widely. Approximately one-third $(n=13)$ of the librarians held a master's degree from an LIS program, and two others were enrolled in LIS master's degree programs at the time of the study. As shown in Table 1, more than $85 \%$ of the participants had a college degree. Participants ranged widely in years of experience in children's library services and/or providing storytime programs from only months of service to several decades $(\mathrm{M}=8.49$ years $)$. More than half of the participants $(57.1 \%)$ had five years or more of experience. Two of the librarians self-identified as male, and all others as female. We did not collect information about librarians' race nor ethnicity.

Table 1. Formal Education of Librarians

\begin{tabular}{lccc}
\hline & $\mathrm{n}$ & $\%$ & Cumulative \% \\
\hline High school diploma & 1 & 2.9 & 2.9 \\
Associate's degree & 4 & 11.4 & 14.3 \\
& & & \\
Bachelor's degree & 13 & 37.1 & 51.4
\end{tabular}


Master's degree

Missing information
16

1
45.7

2.9
97.1

100

We collected no information about the 652 child participants. The number of child participants that we visually appraised as ranging in age from three to five years old in each storytime ranged widely: two storytime programs each had only one child participant, while one storytime program had 44 child participants $(\mathrm{M}=9.59)$.

\section{Data collection}

Our research team pre-scheduled and then observed and video-recorded two storytimes at each participating library between September 2018 and January 2019. Video recordings utilized a two-camera system. One camera was positioned behind the storytime librarian to capture the actions of the children and utterances of the librarian, and the other camera was positioned behind storytime participants to capture the actions of the librarian and utterances of the participants. Because no children came to participate in two storytime programs, at two different libraries, the librarians did not present them. Thus, this analysis is based on a total of 68 storytime sessions provided at 35 public libraries.

\section{CLASS coding procedure}

Three certified CLASS observers scored the storytime observations. Each observation video served as one extended cycle with observers rating interactions on the 10 dimensions across the three domains of the CLASS instrument. Scores on the CLASS are interpreted as follows: ratings of 1 or 2 are considered low; 3 through 5 are medial, and 6 through 7 are high.

To establish reliability, each of the observers first individually scored two randomly-selected storytime observation videos and then the three observers compared results. During this time, points of ambiguity were discussed until a consensus was reached. Intercoder reliability, as assessed by Krippendorff's alpha, was acceptable across all domains and dimensions, reaching a 0.816 agreement. Across several stages, each observer then independently viewed and scored an additional twelve randomly-selected observations. In all, fourteen observations, or $20 \%$ of the overall data set, were scored by all three observers. Intercoder reliability, as assessed by Krippendorf's alpha, was acceptable across all domains and dimensions, reaching a 0.849 agreement. Each of the remaining 54 storytimes were then randomly assigned to one of the three observers and scored independently.

\section{Factors considered in data analysis}


We analyzed the scored data quantitatively using both descriptive and inferential statistics. We first investigated the quality of interactions in the 10 dimensions across the three domains based on descriptive statistics. Then, we identified six factors that might be associated with the librarian's interactions with children in storytime, as follows, and used t-tests and one-way ANOVAs for inferential statistical analysis:

- Population density of the library community

- Librarian's MLIS (or equivalent) degree.

- Librarian's educational level

- Librarian's prior teaching experience

- Librarian's experience in children's library services

- Number of children participating in the storytime

\section{Results}

We first analyzed the mean scores for each dimension and across each domain as presented in Table 2. In the Emotional Support domain, the results reveal that storytimes offer a Positive Climate $(M=5.85)$, and almost no Negative Climate $(M=1.19)$. In the Classroom Organization domain, the average scores ranged between 4.71 and 5.37, indicating medial quality, and in the Instructional Support domain mean values for the dimensions ranged from 1.88 to 2.29, which are quite low compared with the other domain scores.

Table 2. CLASS mean scores for all items

\begin{tabular}{|l|l|l|l|}
\hline Dimension & Item & Mean & SD \\
\hline \multirow{2}{*}{$\begin{array}{l}\text { Emotional } \\
\text { Support }\end{array}$} & Positive Climate & 5.85 & 0.935 \\
\cline { 2 - 4 } & Negative Climate* & 1.19 & 0.388 \\
\cline { 2 - 4 } & Teacher Sensitivity & 4.46 & 1.156 \\
\cline { 2 - 4 } & Regard for Student Perspectives & 4.32 & 1.021 \\
\cline { 2 - 4 } & Sub-total** & 21.44 & 2.883 \\
\hline \multirow{2}{*}{$\begin{array}{l}\text { Classroom } \\
\text { Organization }\end{array}$} & Behavior Management & 4.71 & 1.106 \\
\cline { 2 - 4 } & Productivity & 5.37 & 1.208 \\
\hline
\end{tabular}




\begin{tabular}{|l|l|l|l|}
\hline \multirow{2}{*}{} & Instructional Learning Formats & 4.76 & 1.054 \\
\cline { 2 - 4 } & Sub-total & 14.84 & 2.986 \\
\hline \multirow{3}{*}{$\begin{array}{l}\text { Instructional } \\
\text { Support }\end{array}$} & Concept development & 2.29 & 0.995 \\
\cline { 2 - 4 } & Quality of feedback & 1.88 & 0.836 \\
\cline { 2 - 4 } & Language Modeling & 1.88 & 0.705 \\
\cline { 2 - 4 } & Sub-total & 6.05 & 2.145 \\
\hline Total & & 42.33 & 7.014 \\
\hline
\end{tabular}

*Higher score indicates more negative, vice versa; **For Negative Climate, we recoded the original values reversely.

We investigated differences of CLASS scores by population density of the community the library serves (i.e., urban, urban cluster, and rural areas), LIS master's degree, librarian's educational level, librarian's prior teaching experience, and number of children participating. ANOVA and t-test results at the alpha level of 0.05 indicate no significant differences.

Finally, we examined the CLASS score differences by the storytime librarian's experience in children's services. We made three groups of librarians based on the years they served as a librarian in children's services and conducted a one-way ANOVA. For seven items, we observed statistically significant mean differences at the alpha level of 0.05: Teacher Sensitivity ( $\mathrm{F}(2$, $65)=7.151 ; \mathrm{p}=.002)$, Regard for Student Perspectives $(\mathrm{F}(2,65)=6.992 ; \mathrm{p}=.002)$, Behavior Management $(\mathrm{F}(2,65)=6.618 ; \mathrm{p}=.002)$, Productivity $(\mathrm{F}(2,65)=3.195 ; \mathrm{p}=.047)$, Instructional Learning Formats $(\mathrm{F}(2,65)=5.956 ; \mathrm{p}=.004)$, Concept Development $\mathrm{F}(2,65)=5.538$;

$\mathrm{p}=.006)$, and Language Modeling $(\mathrm{F}(2,65)=5.629 ; \mathrm{p}=.006)$. Post-hoc Tukey HSD tests revealed that librarians with less than 3 years of experience were likely to exhibit lower CLASS scores.

\section{Discussion}

Because interactions between children and adults are the primary driver of development and learning in formal and informal learning environments (Rutter and Maughan 2002) and because children's emotional, self-regulation, and learning outcomes are related to the quality of these interactions (Rimm-Kaufman, Grimm, Curby, Nathanson and Brock 2009), this study focused on librarian-child interactions in public library storytimes and the extent to which those interactions support learning for young children. We further examined whether differences in quality were 
discernible by population density of the library community (i.e. rural, suburban, or urban), librarian qualifications, and number of children participating in the storytime.

To what extent are the interactions between the librarian and children in library storytimes supportive of children's learning and development?

We first analyzed the mean scores for each dimension and across each domain of the CLASS to determine the quality of interactions in terms of Emotional Support, Classroom Organization, and Instructional Support.

\section{Emotional Support}

Findings from this study suggest that through the emotionally supportive environment of storytime, librarians are positioning children to be school ready. Storytimes offer a positive atmosphere $(M=5.85)$ with almost no negative climate $(M=1.19)$. Children who experience emotionally supportive environments exhibit lower levels of stress (Hatfield, Hestenes, KintnerDuffy and O'Brien 2013), better social and cognitive outcomes (Williford, Maier, Downer, Pianta and Howes 2013), and reductions in behavior problems (Mashburn, Pianta, Hamre, Downer, Barbarin and Bryant et al. 2008). In turn, children who exhibit social emotional competence upon school entry have greater success making friends, harbor a more positive regard for school, and perform better academically than less socially competent peers (Raver and Knitzer 2002). Displays of support in storytimes, that are with an adult who is not the primary caregiver, may be particularly beneficial for children who are not enrolled in a preschool program or who have limited interactions with adults outside of their family relationships.

Librarians' demonstrations of sensitivity and regard for child perspectives were of acceptable quality, yet, contextual factors may explain why they were not higher. Specifically, storytimes are typically designed for caregivers to participate along with the children they bring (Neuman et al. 2017); thus, librarians may be counting on caregivers to attend to their children's individual needs. In other words, there may be fewer opportunities for librarians to demonstrate sensitivity toward individual children, or they may feel doing so would interfere in the child-caregiver relationship. Further, because children typically come to storytime only once per week or less frequently (Cahill, Howard and Walker in press; Myrtil, Justice and Jiang 2019), librarians may not have close personal relationships with individual children attending a program. Therefore, it may be more difficult to attend to individual children's perspectives. Still, in some instances scores were lower on the Regard for Student Perspectives component because librarians appeared to be overly committed to sticking with the planned activities rather than responding to the appeals verbalized by the children or behavior cues that signaled children's disinterest in events transpiring.

Findings indicate that, on a whole, interactions in storytimes tend to be emotionally supportive. This emotional support is of particular importance given the primacy caregivers place on child 
enjoyment as a factor in storytime attendance (Cahill et al. in press). Because beliefs about the importance of social emotional learning tend to influence the emotional support adults provide (Zinsser, Shewark, Denham and Curby 2014), librarian professional development organizers might consider providing workshops and trainings focused on social emotional learning and supportive interactions to further bolster the quality of emotional support in storytime.

\section{Classroom Organization}

Classroom Organization dimension scores in the storytime programs observed were in the medial range, with Behavior Management trailing Productivity and Instructional Learning Formats. Because storytimes are designed for high interactivity over a relatively short time frame (Goulding et al. 2017), the level of efficiency reflected in the Productivity score might be expected. Similarly, because storytime programs are designed to incorporate book reading, music, gross motor movements, and other fun and engaging activities aligned to the developmental needs and limitations of young children (Neuman et al. 2017), satisfactory scores are to be expected for Instructional Learning Formats. However, scores might have been higher on this dimension had librarians more frequently employed strategies to focus the children's attention toward learning objectives, either through explicit statements or through summaries at the conclusions of learning segments. Additionally, had librarians more regularly facilitated children's engagement through questions and maximized participation or expanded children's involvement, scores would have been higher. While behavior management is not a problem in most storytimes, the results of this study suggest it is also not an area of strength. Few overt misbehaviors occurred in the storytime program we observed; however, librarians were inconsistent in establishing clear behavior expectations. Librarians who had high quality interactions for Behavior Management proactively attended to positive behaviors and guarded against misbehavior by anticipating problems.

Because children tend to learn more and are better able to regulate attention and behaviors in learning environments that are organized and predictable (Emmer and Stough 2001), storytimes that reflect the dimension of Classroom Organization are important. LIS programs that prepare pre-service librarians recognize changing professional demands and are modifying curricula to address issues such as classroom management (Educators of School Librarians 2019); however, librarians are not necessarily trained as educators and most need professional development to support their role as early childhood educators (Neuman et al. 2017). Additionally, because classroom management is a skill that is learned over time and with practice (Emmer and Stough 2001), professional development organizers should make librarians aware that this type of training is not a "one and done" undertaking.

Instructional Support

Levels of learning support in storytimes are reflected in the Instructional Support dimension scores, the mean values of which ranged from 1.88 to 2.29. Scores for all dimensions reflect 
"low" quality adult-child interactions based on the CLASS scoring system and in comparison to the dimension scores in the other two domains of this analysis. These findings intimate much room for improvement in terms of learning support in storytimes, and while they are consistent with instructional support scores reported in typical preschool classrooms (Burchinal, Howes, Pianta, Bryant, Early, Clifford et al. 2008; Mashburn et al. 2008) and classrooms serving children with special needs (Guo, Sawyer, Justice and Kaderavek 2013), they are nonetheless disappointing, primarily because shared reading events offer many opportunities for instructional interaction (Cabell, DeCoster, LoCasale-Crouch, Hamre and Pianta 2013; Dickinson and Smith 1994). Further, library associations have focused much attention and resources toward integrating early literacy strategies into storytime (Albright, Delecki and Hinkle 2009) and provided professional development to prepare librarians to model and teach early literacy skills in storytime programs (Neuman et al. 2017).

While there were instances of effective interactions in the Concept Development, Quality of Feedback and Language Modeling dimensions in most storytimes, these interactions were either low in frequency or employed inconsistently; thus, no observations merited a high score. To be sure, some librarians did score in the mid-range in this domain. Those librarians whose interactions were scored as medial in Concept Development used discussions and questioning strategies to promote higher order thinking skills. For example, one storytime librarian linked a concept to the children's own lives, encouraging them to imagine what they would do if they were in the same situation as the character. Another librarian prompted children to engage in analytic reasoning, urging them to explain what might happen if they put bubble gum in a washing machine. Librarians who scored in the mid-range on Quality of Feedback offered additional information that expanded conversations and children's understanding employing strategies to stretch children's thinking. In one instance a librarian scaffolded a child's explanation of an event via targeted questions, and another librarian prodded a child to expound on a response by supplying a rationale. Observations that scored in the medial range on Language Modeling included frequent conversations, open-ended questions, repetition, and advanced language. For example, in one storytime a book contained text about birds flying away from the cold climate, and the librarian explained that the birds were migrating and then facilitated a discussion about migration.

Influence of other factors on the quality of the interactions between the librarian and children in storytimes

We investigated differences of CLASS scores by population density of the community the library serves (i.e., urban, urban cluster, and rural areas) and found no statistically significant differences across the 10 dimensions indicating that interaction quality is fairly consistent across urban, suburban, and rural libraries. Although prior research suggests that learning environments differ based on community factors (Neuman et al.,2001) with children in rural areas having limited opportunities for high-quality learning opportunities (Iruka, DeKraai, Walther, Sheridan 
and Abdel-Monem 2020), libraries are one asset that can serve as an equalizer across the rural to urban spectrum. Libraries in many rural communities are celebrated as learning resources that provide a high social return on investment (Broad, Ortiz and Meades 2019), in part because they serve as one of the few places for children to play and learn (Barnyak 2011; Samsuddin, Shaffril and Fauzi 2019). Libraries in urban communities serve as an especially valuable literacy resource for families experiencing hardship (MacGillivray, Ardell and Curwen 2010), and through tailored and targeted programming, they have the potential to level the playing field for those families who are less socio-economically equipped (Neuman et al. 2012).

Level of teacher education has been found to be a predictor of interaction quality in preschool classrooms (Pelatti, Dynia, Logan, Justice and Kaderavek 2016); thus, it might be surprising that we found no significant differences for any of the ten CLASS dimensions based on librarians' prior experience as a teacher nor educational preparation, implying that storytime librarians would provide similar levels of interaction quality regardless of their educational background including attainment of an MLIS degree. LIS scholars have recently sounded alarms that LIS programs could do better at preparing librarians to address the needs of the patrons whom they are being prepared to serve (Abels, Howarth and Smith 2016; Caspe and Lopez 2018; Jaeger, Bertot and Subramaniam 2013).

On the other hand, years of experience is not considered a quality indicator in early childhood classrooms (McMullen, Perlman, Falenchuk, Kamkar, Fletcher, Brunsek et al. 2020), meaning that a teacher's years of experience is not associated with child outcomes. Yet, our results point to differences for seven of the ten dimensions based on years of experience in library services: Teacher Sensitivity, Regard for Student Perspectives, Behavior Management, Productivity, Instructional Learning Formats, Concept Development, and Language Modeling. Post-hoc tests revealed that librarians with 3 or more years of experience were likely to exhibit higher CLASS scores than their less experienced peers, indicating librarians' abilities to improve with practice and training. These results may point to the value of professional development which public library directors identify as an important support for storytime librarians (Cahill et al. 2020).

Finally, we examined differences in interaction quality between small, medium and large size storytime programs. We found no statistically significant association between the number of participating children and the quality ratings in any of the dimensions. In the preschool context, more adult-child interactions transpire in classrooms with fewer children; however, the quality of the learning experience, as measured by quality of interactions, does not necessarily differ between smaller and larger classrooms (Francis and Barnett 2019). On the other hand, investigations of interactions during read-aloud in early childhood classrooms indicate differences based on seating arrangement (Paciga, Lisy and Teale 2009) and group size (Phillips and Twardosz 2003), with increases in children's engagement based on proximity to the reader and smaller group size. Therefore, even though we did not identify differences at the group level, 
it might be valuable in the future to examine differences in the quality of interactions at the individual level for different children and different groups of children.

\section{Conclusions}

It is imperative that librarians support children's social and emotional functioning, selfregulatory skills, and cognitive and language development if public library storytimes are to be truly recognized as school readiness venues. Results from the current investigation indicate that librarians are providing quality interactions in the Emotional Support and Organizational Support domains, but that storytime programs could provide better Instructional Support. Few other studies of adult-child interactions have taken place in informal learning contexts beyond the classrooms and homes of young children, and very little empirical evidence exists to measure or support the development of high-quality public library storytime programming. This study contributes to the professional knowledge base in both areas and establishes a base upon which additional research might build. 


\section{References}

Abels, E. G., Howarth, L. C., \& Smith, L.C. (2016). Envisioning our information future and how to educate for it. Journal of Education for Library \& Information Science, 57(2), 84-93.

Albright, M., Delecki, K., \& Hinkle, S. (2009). The evolution of early literacy. Children \& Libraries 7(1), 13-18.

Arnold, D. H., Kupersmidt, J. B., Vogler-Lee, M. E., \& Marshall, N. A. (2012). The association between preschool children's social functioning and their emergent academic skills. Early Childhood Research Quarterly 27(3), 376-386.

Barnyak, N. C. (2011). A qualitative study in a rural community: Investigating the attitudes, beliefs, and interactions of young children and their parents regarding storybook read alouds. Early Childhood Education Journal 39(2), 149-159.

Bowlby, J. (1958). The nature of the child's tie to his mother. International Journal of Psychoanalysis 39, 350-371.

Broad, G., Ortiz, J., \& Meades, S. (2019). Public libraries: Measuring their value. Public Library Quarterly 38(3), 309-319.

Burchinal, M., Howes, C., Pianta, R., Bryant, D., Early, D., Clifford, R., \& Barbarin, O. (2008). Predicting child outcomes at the end of kindergarten from the quality of prekindergarten teacher-child interactions and instruction. Applied Developmental Science 12(3), 140153.

Cabell, S. Q., DeCoster, J., LoCasale-Crouch, J., Hamre, B. K., \& Pianta, R. C. (2013). Variation in the effectiveness of instructional interactions across preschool classroom settings and learning activities. Early Childhood Research Quarterly 28(4), 820-830.

Cahill, M., Joo, S., Howard, M., Ingraham-Dwyer, J., King-Oaks, K., \& Yates, B. (2020). What is storytime good for, and what makes storytime good? A survey of public library directors. Journal of Librarianship \& Information Science, https://doi.org/10.1177/0961000619898224.

Cahill, M., Joo, S., Howard, M., \& Walker, S. (in press). We've been offering it for years, but why do they come? The reasons why adults bring young children to public library storytimes. Libri.

Campana, K., Mills, J. E., Capps, J. L., Dresang, E. T., Carlyle, A., Metoyer, C. A., Urban, I. B., Feldman, E. N., Brouwer, M., Burnett, K., \& Kotrla, B. (2016). Early literacy in library storytimes: A Study of measures of effectiveness. Library Quarterly 86(4), 369-388.

Campana, K. (2018). The multimodal power of storytime: Exploring an information environment for young children (Publication No. 10825573.) [PhD Thesis, University of Washington]. ProQuest Dissertations Publishing.

Caspe, M., \& Lopez, M. E. (2018). Preparing the next generation of librarians for family and community engagement. Journal of Education for Library \& Information Science 59(4), $157-178$. 
Child Trends. (2015). Early school readiness: Indicators of child and youth well-being. Report. Child Trends. https://www.childtrends.org/wpcontent/uploads/2015/01/indicator_1422334019.296.html. Accessed 10 September 2020.

Dickinson, D. K., \& Porche, M. V. (2011). Relation between language experiences in preschool classrooms and children's kindergarten and fourth-grade language and reading abilities. Child Development 82(3), 870-886.

Dickinson, D., \& Smith, M. W. (1994). Long-term effects of preschool teachers' book readings on low-income children's vocabulary and story comprehension. Reading Research Quarterly 29(2), 104-122.

Educators of school librarians. (2019). 'Item 5: curriculum discussion'. Minutes of educators of school librarians section meeting 22 June 2019. American Association of School Librarians: Washington, DC.

Emmer, E. T., \& Stough, L. (2001). Classroom management: A critical part of educational psychology, with implications for teacher education. Educational Psychologist 36(2), 103-112.

Francis, J., \& Barnett, W. S. (2019). Relating preschool class size to classroom quality and student achievement. Early Childhood Research Quarterly 49, 49-58.

Ghoting, S., \& Martin-Diaz, P. (2013). Storytimes for everyone! Developing young children's language and literacy. Chicago: American Library Association.

Goulding, A., Dickie, J, \& Shuker, M. J. (2017). Observing preschool storytime practices in Aotearoa New Zealand's urban public libraries. Library \& Information Science Research 39(3), 199-212.

Guo, Y., Sawyer, B. E., Justice, L. M., and Kaderavek, J. N. (2013). Quality of the literacy environment in inclusive early childhood special education classrooms. Journal of Early Intervention 35(1), 40-60.

Haycock, K. (2016). The future of libraries: More questions than answers. Public Library Quarterly 35(4), 291-297.

Hamre, B. K., Pianta, R. C., Downer, J. T., DeCoster, J., Mashburn, A. T., Jones, S. M., Brown J. L., Cappella, E., Atkins, M., Rivers, S. E., Brackett, M. A., \& Hamagami, A. (2013). Teaching through interactions: Testing a developmental framework of teacher effectiveness in over 4,000 classrooms. The Elementary School Journal 113(4), 461-487.

Hatfield, B. E., Hestenes, L.L., Kintner-Duffy, V.L., \& O’Brien, M. (2013). Classroom Emotional Support predicts differences in preschool children's cortisol and alphaamylase levels. Early Childhood Research Quarterly 28(2), 347-356.

Hill, C., Proffitt, M., Streams, S., \& OCLC. (2015). IMLS focus: Learning in libraries. Report. Institute of Museum and Library Services. https:/www.imls.gov/publications/imls-focussummary-report-learning-libraries. Accessed 10 September 2020.

Hussar, B., National Center for Education Statistics, Zhang, J., Hein, S., Wang, K., Roberts, A., Cui, J., Smith, M., Bullock Mann, F., Barmer A., \& Dilig, R. (2020). The condition of education 2020, preprimary education. Report. National Center for Education Statistics. https://nces.ed.gov/pubs2020/2020144.pdf. 10 September 2020. 
Institute of Museum and Library Services. (2016). Public libraries survey. Resource documents. IMLS. https://www.imls.gov/research-evaluation/data-collection/public-libraries-survey. Accessed 10 September 2020.

Institute of Museum and Library Services. (2020) Public libraries in the United States: Fiscal year 2017, volume I. Report. IMLS.

https://www.imls.gov/sites/default/files//publications/documents/publiclibrariesintheunite dstatessurveyfiscalyear2017volume1.pdf. Accessed 10 September 2020.

Iruka, I. U., DeKraai, M., Walther, J., Sheridan, S. M., \& Abdel-Monem, T. (2020). Examining how rural ecological contexts influence children's early learning opportunities. Early Childhood Research Quarterly 52, 15-29.

Jaeger, P. T., Bertot, J. C., \& Subramaniam, M. (2013). Preparing future librarians to effectively serve their communities. Library Quarterly 83(3), 243-248.

John-Steiner, V., \& Mahn, H. (1996). Sociocultural approaches to learning and development: A Vygotskian framework. Educational Psychologist 31(3), 191-206.

MacGillivray, L., Ardell, A. L., and Curwen, M. S. (2010). Libraries, churches, and schools: The literate lives of mothers and children in a homeless shelter. Urban Education 45(2), 221245.

Mashburn, A. J., Pianta, R., Hamre, B. K., Downer, J. T., Barbarin, O., Bryant, D., Burchinal, M., Clifford, R., Early, D. \& Howes, C. (2008). Measures of classroom quality in prekindergarten and children's development of academic, language and social skills. Child Development 79(3), 732-749.

McKend, H. (2010). Early literacy storytimes for preschoolers in public libraries. Report. Provincial and Territorial Public Library Council. https://ptplc-dev.libraries.coop/wpcontent/uploads/2015/12/early_lit_storytimes_final_english_with_cip_electronic_nov10. pdf. Accessed 12 August 2020.

McMullen, E., Perlman, M., Falenchuk, O., Kamkar, N., Fletcher, B., Brunsek, A., Nocita, G. \& Shah, P. S. (2020). Is educators' years of experience in early childhood education and care settings associated with child outcomes? A systematic review and meta-analysis. Early Childhood Research Quarterly 53: 171-184.

Myrtil, J. M., Justice, L. M, \& Jiang, H. (2019). Home-literacy environment of low-income rural families: Association with child- and caregiver-level characteristics. Journal of Applied Developmental Psychology 60, 1-10.

Neuman, S. B., Moland, N. \& Celano, D. (2001). Access to print in low-income and middleincome communities: An ecological study of four neighborhoods. Reading Research Quarterly 36(1), 8-26.

Neuman, S. B., Moland, N., \& Celano, D. (2012). Worlds apart: One city, two libraries, and ten years of watching inequality grow. American Educator 36(3), 13-23.

Neuman, S. B., Moland, N. \& Celano, D. (2017). Bringing literacy home: An evaluation of the Every Child Ready to Read program. Report. American Library Association. http://everychildreadytoread.org/wp-content/uploads/2017/11/2017-ECRR-ReportFinal.pdf. Accessed 12 August 2020. 
NICHD Early Child Care Research Network. (2005). Pathways to reading: The role of oral language in the transition to reading. Developmental Psychology 41(2), 428-442.

Office of Head Start. (2015). Head Start early learning outcomes framework: Ages birth to five. Resource document. Head Start Early Learning and Knowledge Center. https://eclkc.ohs.acf.hhs.gov/sites/default/files/pdf/elof-ohs-framework.pdf. Accessed 12 August 2020.

Paciga, K. A., Lisy, J. G., \& Teale, W. H. (2009). Examining student engagement in preschool read alouds. In: K. Leander, D. W. Rowe, D. K. Dickinson, M. K. Hundley, R. T. Jimenez \& V. J. Risko (Eds.), 58th Yearbook of the national reading conference (pp.330347). Oak Creek, WI: National Reading Conference.

Pelatti, C. Y., Dynia, J. M., Logan, J. A. R., Justice L. M., \& Kaderavek, J. (2016). Examining quality in two preschool settings: Publicly funded early childhood education and inclusive early childhood education classrooms. Child \& Youth Care Forum 45(6), 829849.

Peterson, S. S., Jang, E., Jupiter, C., \& Dunlop, M. (2012). Preschool early literacy programs in Ontario public libraries. Partnership: The Canadian Journal of Library and Information Practice and Research 7(2), 1-22.

Phillips, L. B., \& Twardosz, S. (2003). Group size and storybook reading: Two-year-old children's verbal and nonverbal participation with books. Early Education and Development 14(4), 453-478.

Pianta, R. C., LaParo, K. M., \& Hamre, B. K. (2013). Classroom assessment scoring system manual, pre-k. Charlottesville, VA: Teachstone.

Raver, C. C., \& Knitzer, J. (2002). Ready to enter: What research tells policymakers about strategies to promote social and emotional school readiness among three- and four-yearolds. Report. National Center for Children in Poverty. https://www.researchgate.net/publication/5091232_Ready_to_Enter_What_Research_Tel 1s_Policymakers_About_Strategies_to_Promote_Social_and_Emotional_School_Readine ss_Among_Three-_and_Four-Year-Olds. 10 September 2020.

Rimm-Kaufman, S. E., Grimm, K. J., Curby, T. W., Nathanson, L. \& Brock, L. L. (2009). The contribution of children's self-regulation and classroom quality to children's adaptive behaviors in the kindergarten classroom. Developmental Psychology 45(4), 958-972.

Rutter, M., \& Maughan, B. (2002). School effectiveness findings 1979-2002. Journal of School Psychology 40(6), 451-475.

Samsuddin, S. F., Shaffril, H. A. M., \& Fauzi, A. (2019). Heigh-ho, heigh-ho, to the rural libraries we go! A systematic literature review. Library and Information Science Research, https://doi.org/10.1016/j.lisr.2019.100997.

Sirinides, P., Fink, R., \& Dubois, T. (2017). A Study of early learning services in museums and libraries. Early Childhood Education Journal 45(4), 563-573.

Vitiello, V. E., Bassok, D., Hamre, B. K., Player, D. \& Williford, A. P. (2018). Measuring the quality of teacher-child interactions at scale: Comparing research-based and state observation approaches. Early Childhood Research Quarterly 44: 161-169. 
Williford, A. P., Maier, M. F., Downer, J. T., Pianta, R. C., \& Howes C (2013). Understanding how children's engagement and teachers' interactions combine to predict school readiness. Journal of Applied Developmental Psychology 34(6), 299-309.

Zinsser, K. M., Shewark, E. A., Denham, S. A., \& Curby, T. W. (2014). A mixed-method examination of preschool teacher beliefs about social-emotional learning and relations to observed emotional support. Infant and Child Development 23(5), 471-493. 